\title{
LITERATURE ON STUDENT BOOK AND ITS EFFECT FOR DEVELOPING ELEMENTARY SCHOOL TEACHING MATERIALS
}

\author{
Emi Febrina Ningrum \\ Primary Education, Postgraduate Program, Yogyakarta State University \\ Jl. Colombo, No.1, Caturtunggal, D. I. Yogyakarta 55281, Indonesia \\ febrinaemi@gmail.com
}

Received: $10^{\text {th }}$ January 2018/Revised: $07^{\text {th }}$ February 2018/Accepted: $20^{\text {th }}$ February 2018

How to Cite: Ningrum, E. F. (2018). Literature on student book and its effect for developing elementary school teaching materials. Lingua Cultura, 12(2), 209-214.

https://doi.org/10.21512/lc.v12i2.4284

\begin{abstract}
This research applied the qualitative research content analysis on the 4th grade of elementary school students which aimed to know the literary material contained in the 2013 curriculum student book in Indonesia as the compulsory guidebook. The results of this research could be useful for guidelines for the development of literary materials by teachers when implementing learning planning. The findings show that students' literature material is only about $30 \%$ of the Indonesian language learning material found in the $4^{\text {th }}$ grade of elementary school. The lesson was limited to reading the text of the story then answering questions about the content of the text. In general, literary competence material in student books has not been emphasized on the cultivation of literary concepts. The development of literary materials in the $4^{\text {th }}$ grade of elementary school should include the introduction of literary concepts, analyzing the contents of literary texts, and applying moral values in literature to be applied in daily life.
\end{abstract}

Keywords: literary books, literary learning, elementary school material, teaching development

\section{INTRODUCTION}

Elements of life found in literature make each literary work contain useful moral values in the educational world. Therefore, literature becomes a part of the lesson materials learned in various schools in the world. Some countries using literature in their school curriculums are Greek (Aravani, 2012), United States, German (Wally, Levinger, \& Grainger, 2005), and Indonesia (Djuanda, 2014).

In Indonesia, literature becomes a part of learning curriculum from elementary school. Literature is included in Indonesian language learning material for elementary school (Kemendikbud, 2013). It is included in the evaluation category of Progress in International Reading Literacy Study (PIRLS) 2011 as a survey conducted for IV grade students in elementary schools (Suryaman, 2015). Indonesia has the $42^{\text {nd }}$ rank of 60 participating states. Various studies have been conducted to maximize literary learning to increase the literary competence of students, use of literature to develop other lesson materials, and moral values of literary learning in elementary schools. Meanwhile, analysis of literary materials in elementary school books for students in Indonesia is less specific to get attention. As one way to meet the need, this research analyzes literary materials in elementary school books for students. The results of research can be used as the guideline in developing literary teaching materials which should be done by teachers so that the literary learning can be maximum.

The literature contains elements of feeling, beauty, language play, and meaning. Literary work is different from non-literary work because the former contains beauty when its contents are enjoyed. Literature learned in elementary schools is included in children literature. Children literature is a child literary where its contents and language are consistent with intellectual and emotional progress level of children. The benefit of children literature is to increase children love to read, being a key to science. It is also able to develop aspects of cognitive, affective, and psychomotor intelligence of the children because it needs contemplation, idea precipitation, maturity, specific steps which will be different between one author and others. Form, style, and language are used in a typical literary work. Literary work has specific logic and beauty (Siswanto, 2013).

Literary learning is learning, which tries to develop a literary appreciation competence, literary critique, and literary-creative process. Learned appreciation competence is the competence to enjoy and appreciate literary work. Students are directly asked to read, analyze, and enjoy literary work. Learning of literary critique will develop the competence of students to understand and evaluate literary 
work. Creative learning of literature tries to teach students to write literary work (Siswanto, 2013).

Indonesian language learning in elementary schools consists of two parts, namely, the competence of students to speak and appreciate literature. Literary teaching aims at increasing the competence of students to enjoy, implement, and understand literary work. Educational values, which can be absorbed by kids from literary readings, are to help develop language, improve competence to read, increase competence to write (Djuanda, 2014). Through literature, students feel easier to self-express, dare to suggest, dare to think differently and become more enthusiastic in developing imagination. In addition, the students will gain many moral educations, which are gained by the unusual way but these are pleasuring and concerning thought. The use of literature should become the materials which cannot be separated from education and teaching in each of age and education levels (Irawati \& Purwani, 2013).

Curriculum in Indonesia has repeatedly been improved. The recent improvement is to change learning into theme-based called as 2013 curriculum that uses thematic-integrative approach. Indonesian language lesson is used to drag other lessons. Combination of other lessons in Indonesian language lesson makes Indonesian language lesson becomes contextual, so its learning is more attractive. Indonesian language lesson is included in lesson whose contents are developed by the central in more times than other lessons, namely, 7-hour learning per week (Kemendikbud, 2013). It proves that the Indonesian language lesson becomes a vital lesson to teach in elementary schools.

Generally, Indonesian language learning designed in 2013 curriculum is text-based learning. The text is presented as material, which is studied for various lessons. Four aspects of language skills are to scrutinize, read, write, and speak lead in the curriculum, but literary learning materials in the 2013 curriculum are less than the previous one (Wulan, 2014).

Language teaching material is everything consciously used to increase students' language experience and knowledge. Materials may be video, DVD, email, YouTube, dictionary, grammar book, worksheet, and workbook of students (Tomlinson, 2011). Teaching materials are associated with competence, which must be owned by students after following specific learning. It implies that, in arranging teaching materials, it is needed to consider coverage of teaching materials with presentation systematic, namely, from the simple to the complex.

To produce quality teaching materials, it is needed the specific criteria as the benchmark. The good teaching materials must have the following criteria; (a) novelty (such as unusual topic, illustration and activity); (b) variety (such as, solving unit boring routinely with unexpected activities and using many different text types taken from various source types; (c) attractive presentation (such as use of attractive color); (d) appealing content (such as attractive topic for students); (e) achievable challenge (such as challenging task for students to think) (Tomlison, 2011).

Teaching materials consist of three following aspects: knowledge (fact, concept, principle, and procedure), skill, and attitude (value) (Prastowo, 2012). Knowledge is associated with understanding, characteristics, and types of literary works, whereas skill is related to the process of literary appreciation, and finally attitude is associated with values gained after appreciating literature. Literary work has the specific mandate, which is applicable to daily life.

Various studies on literature in elementary schools have been conducted in both Indonesia and other countries. It is the background of how important the literary learning to be applied to maximize the benefit of literature so students can really feel that. In elementary school age, according to Piaget, students are included in the concrete-operational stage. The operation is a reversible mental action, while the concrete operation is action applicable to concrete and real object (Santrock, 2011). Students have been able to understand and interpret oral and written communication to make students understand (Papalia \& Feldman, 2014). Therefore, various studies on the use of literature to develop language and moral of students are conducted in elementary schools.

Arravani (2012) has researched on systematic teaching to read poetry in Greek elementary schools is to increase the attraction of children in reading and helping their oral skill by enriching their glossaries and creative thinking. Design of teaching is based on Rosenblatt's transactional theory. Findings indicate that: (a) small children illustrate poetry programs as a most pleasuring part of language art; (b) involvement and motivation to increase children' reading and (c) through poetry programs, children develop the better reading skill.

Wally, Levinge, and Grainger (2005) have researched on the cultural theme can be an effective medium to attract students in science. Programs described here uses current kid literature in multi-purpose chemical lesson activities. These activities produce excitement for elementary school students because integration of literary series by Harry Potter is famous for the direct experiment.

Djuanda (2014) has researched about literary learning in 2013 curriculum is literary activities that get few better portion. The curriculum approach signalizes the pressure on development of attitude and character, where literature is the rich material to be a basis to sharpen personality and character. Considering that, the literature contains extraordinary personal and educational values. Results of basic competence analysis of Permendikbud No.57/2014 indicate that literary materials included in book contents are less sufficient (very less sufficient) because contents of teacher and student books, derivatives of Basic Competence have already been mapped thematically-integrally.

Next is research by Nensilianti (2012) on competence to interpret elementary school students' story. This research uses the pre-experimental quantitative approach. Results of research indicate that the model of story mapping is effectively applicable to increasing of competence to appreciate the story of 5th-grade students of elementary schools. Other research is the development of enrichment book to write kid stories containing character values based on Content and Language Integrated Learning (CLIL) for elementary school students with high class. This character values describe the development and determine the effectiveness of enrichment book (Neina, Mardikantoro, \& Supriyanto, 2015).

Viewed from important literary learning for elementary school students, this research aims at understanding literary materials found in student book of 2013 curriculum in Indonesia as compulsory manual used for most students in Indonesia. So, the results of this research can be useful for the guideline to develop literary teaching material by teachers when they are planning learning. Literary materials are not found in student book yet can be added to the development of teaching materials that are completed by teachers. In details, this research tries to answer the following questions: (1) are there any 
literary materials found in student book of the $4^{\text {th }}$ grade of elementary school in Indonesia? (2) What are depth literary materials found in the book of 4th-grade students of elementary schools in Indonesia? (3) What is the design of literary teaching material development for $4^{\text {th }}$-grade students in elementary school, which should be organized by teachers?

\section{METHODS}

This research adopts the qualitative method using literary study method with content analysis. Content analysis is also meant as a systematic technique to analyze message meanings and way to express messages. Initially, content analysis develops in communication science world, but its development is now used in various sciences, including the literary world.

Content analysis aims at; (a) describing the tendency of communication contents/messages, (b) tracing scientific development, (c) exposing difference in communication/ messages, (d) comparing media or level of communication/ messages, (e) displaying propaganda technique, (f) detecting presence of propaganda or closed ideology, (g) finding style peculiarity, and $(\mathrm{h})$ identifying intention and characteristic of communicator/writer. Although there is quantitative characteristic, content analysis develops into a qualitative form (Krippendorf, 2004). The qualitative content analysis develops and roots from literary study, social study, and contemporary critic studies such as cultural studies and feminist theory. Point of content analysis is to understand the contents and purpose of a text. To understand contents, it needs the descriptive study to understand the purpose of the text. It makes inferences and interpretations based on analysis construction.

Subjects of this research are student books of 2013 Curriculum used by $4^{\text {th }}$ grade of elementary school students in Indonesia. It becomes the subjects because these books are used by nearly all elementary school students in Indonesia that are applying 2013 Curriculum. Parts of the studied book include Indonesian language lesson in lesson integration part. Analyzed student books are nine books with different themes. Data collection techniques used in this research is observation. The researcher observes literary material content in the book for the 4th-grade students. The observations are recorded to be analyzed later.

Researcher uses the method of content analysis in analyzing. During that process, the first thing to do is to classify the data. Data analysis is a series of studying, grouping, systematization, interpretation, and verification of data so that the data will have social, academic, and scientific value. In this research, the researcher wants to know the percentage and how deep the literary material included in the $4^{\text {th }}$-grade student book. Data analysis is performed with a table of basic competencies and literature learning activities that contain in the book. The researcher analyzes the suitability and depth of the data from material presented so that it could obtain a draft of literature teaching materials that need to be developed by teachers to complete shortages of students' books.

\section{RESULTS AND DISCUSSIONS}

According to this research, it can be considered that; (1) how many percentages of literary material in the subject
Indonesian Language for 4th-grade students? (2) What kind of literary material that contained in that book. After that, every literature material will be studied how deep the sense of literature contained. The shortages will appear as this analysis is finished and the future development will be conducted.

The 4th-grade student's books in the 2013 curriculum consist of nine themes. The themes are; (1) The beautiful of togetherness, (2) Always save the energy, (3) Caring toward other beings, (4) Job sharing, (5) My hero, (6) My goals, (7) The beautiful of diversity in my country, (8) My living place, (9) How rich my country is. Every material in those themes is integrated into Indonesian Language subject. Materials of Indonesian Language are selected from 20 basic competencies applied in MoE Regulation No 24 the Year 2016 about main and basic competencies in the 2013 curriculum for basic and middle education phase.

Based on the 2013 curriculum, the basic competencies of Indonesian Language for the $4^{\text {th }}$ grade students are as follow: (3.1) Look at the main and supporting ideas that come from the texts, writings, or visual media. (4.1) Organize the information that come from the texts according to the interrelation among ideas into the draft. (3.2) Look at the interrelation among ideas that come from texts, writings, or visual media. (4.2) Presenting the result of observation pertaining to the interrelation among ideas into the writing. (3.3) Look for an information from one figure through interview by using a list of questions. (4.3) Reporting the result of the interview using proper language and sentences in the paper. (3.4) Comparing two different procedure text on how to use stuffs. (4.4) Presenting the procedure in the paper and oral method by using proper language and sentences. (3.5) Explain the personal statement about content of the literature books (story, folklore, etc). (4.5) Communicate that personal statement with supporting reasons and argument in the paper and oral method. (3.6) Look for the content and moral value of a written and spoken poem for entertainment purposes. (4.6) Read the poem made by themselves in a proper way and expression. (3.7) Look for new knowledge in the non-fictional text. (4.7) Deliver to the class about that new knowledge. (3.8) Compare the new and past information from the non-fictional text. (4.8) Deliver to the class about the result of comparison. (3.9) Pay attention to the figures on the fictional text. (4.9) Deliver to the class about the result of figures' identification. (3.10) Compare the character of each figures. (4.10) Deliver the result of that figures' comparison.

Literature learning process in the 4th-grade student's book in Indonesia can be found only in three themes, one theme in the first semester, and two themes in the second semester. Those themes are Theme 4 (Job sharing), Theme 6 (My goals), and Theme 8 (My living place). Meanwhile, there are only eight points of basic literature competencies in the Indonesian Language out of 20 included. It shows that there is more activity in language development than literacy ability of the student. If it counts percentage, the literacy material for the student is only approximately $30 \%$ of all material of Indonesian Language for the $4^{\text {th }}$-grade student.

Literacy material that is contained in Indonesian Language subject should be analyzed in every learning activity in literacy competency. The analysis should be conducted by matching the indicators with learning competencies to see the depth of material that will be presented in the book. After that, the learning material will be matched to the indicators to see its suitability.

According to the analysis, literacy material in the 
student's book can be seen in Table 1. It can be seen that literacy material for the $4^{\text {th }}$-grade students can build a personal statement about the content of the literature books (story, folklore, etc.) through intrinsic elements and poem appreciation. Those do analyze the content and moral value and supporting poem elements following with write and read the poem, also identify fictional text with its elements. From the basic competencies applied, the indicator of literacy competencies for the 4th grade student are; (1) identify intrinsic element of the story, (2) find the moral value with personal statement, (3) assess the comment toward a folklore, (4) present the assessment toward the story's elements (figures, conflicts, moral value), (5) explain the arguments and reasons of the assessment, (6) identify the poem, (7) identify the message of the poem, (8) identify the structure of the poem, (9) write the poem, (10) read the selfwritten poem in a proper way and expression, (11) identify the figure of fictional story, (12) identify the character of figures of the fictional story, and (13) presenting the result of identification.

Table 1 Basic Competencies, Indicators, and Literacy Material for the $4^{\text {th }}$ Grade Student

Basic Competencies
Building a personal
statement about the
content of literacy
books (story, folk-
lore, etc)

\section{Indicators}

(1) Identify in- 1. Definition of
trinsic element kid's literacy. of the story; (2) 2. Differences Assess the story's between kid's element by using literacy and personal state- other readings. ment; and (3) 3. Intrinsic eleGiving comment ments of kid's toward a folklore. story. toward the story.

Communicating the (1) Present the personal statement intrinsic elements about content of lit- of the story (figeracy books with ures, conflicts, supporting arguments moral values) by and reasons in written using personal and spoken way.

\section{statement and (2)} explain the reasons and arguments of story's assessment in written and spoken way.

Look for the content and message of the poem with entertainment purposes.

(1) Identify the content of the poem; (2) Identify the message of the poem; and (3) Identify the number of lines and rhymes of the poem.

Read the self-written (1) Write a poem in proper way and ex- and (2) Read the pression as the meth- poem in a proper od of self-expression. way and expression. 1. Intrinsic elements of the poem.

2. Technique to write a poem.

3. Technique to read a poem.
4. Assessment

Table 1 Basic Competencies, Indicators, and Literacy Material for the $4^{\text {th }}$ Grade Student (Continued)

\begin{tabular}{|c|c|c|}
\hline Basic Competencies & Indicators & Materials \\
\hline $\begin{array}{l}\text { Look at the figures on } \\
\text { the fictional text. } \\
\text { Compare the charac- } \\
\text { ter of each figures. }\end{array}$ & $\begin{array}{l}\text { (1) Identify the } \\
\text { figures of fiction- } \\
\text { al story and (2) } \\
\text { Identify the char- } \\
\text { acters. }\end{array}$ & $\begin{array}{l}\text { 1. Definition of } \\
\text { fictional story. } \\
2 \text {. Differences } \\
\text { between fic- } \\
\text { tional and non- } \\
\text { fictional story. } \\
\text { 3. Intrinsic el- } \\
\text { ements on fic- } \\
\text { tional story. }\end{array}$ \\
\hline $\begin{array}{l}\text { Deliver the result of } \\
\text { figure's identifica- } \\
\text { tion. } \\
\text { Deliver the result of } \\
\text { that figures' compari- } \\
\text { son. }\end{array}$ & $\begin{array}{l}\text { Presenting the } \\
\text { result of fictional } \\
\text { story's identifica- } \\
\text { tion. }\end{array}$ & \\
\hline
\end{tabular}

According to the analysis of basic competencies and indicators, so it gets a list of learning material that supposed to be presented in student's book. The material that supposed to be presented in competency to build personal statement about the content of literature books is the definition of kid's literacy, differences between kid's literacy and other readings, intrinsic elements, and assessment toward intrinsic elements of the story. In the competency of the poem with content and message that look for entertainment purposes can be showed by intrinsic elements of the poem, the technique of writing, and reading a poem. In the competency that pays attention to the figures of fiction's story, it consists of the definition of a fictional story, differences between fictional and non-fictional story, and intrinsic elements of the fictional story.

According to basic competencies analysis, indicators, and literacy material that presented in the student's book, it is known that there is a lack of literacy material. In theme 4 about competency to build personal statement toward the content of literacy story, the majority of the learning process is about read literacy text (kid's story) and followed by questions pertaining to that text. Therefore, the student's concept of definition and differences of literacy text is not achieved. The presented literacy text is a chosen text by integrating other subjects. Then, explanation about the type of text and supporting literacy element is not presented yet. It implies the narrow understanding of the student. Meanwhile, now it is the time to teach the student about literacy concept.

In Theme 6 on competency to identify the content and message of poetry, there are also presenting the poetry's shortage. First, there is no literacy material about differences of poetry with other literatures. Meanwhile, it becomes more important for teachers to teach this concept to their student so that when the students are asked to write a poem, they know what they should write. Second, the material of poetry writing is limited to verse (pantun), and modern poetry, there is no clear classification of types of poetry. Third, the explanation is limited to lines and rhymes. While the other poem's elements are not discussed yet in the book. Fourth, in the basic competencies, there is the activity to read poetry in a proper way and intonation, but there is no guidance on how to read the poetry properly in the book. Moreover, this 
material is important as one of the basic knowledge of the student so that they can explore more about creative writing since it is the most literature practice compare to other writing activities.

Theme 8 on identifying characters in a fictional text also has the shortage. There are no explanations of the types of the fictional story although the book has been using various kinds of text. It becomes an issue since the students need literacy understanding to identify fictional stories. Then, there is no learning material to differ between fictional and non-fictional text. It needs the emphasizing the characteristic feature of that kind of text with its example.

Lack of literary material in the book of the 4 th grade in elementary school is caused by the inclusion of science subjects and social subjects in Indonesian subjects. Every literary text contained in Indonesian subjects is used to convey IPA (sciences) and IPS (socials) materials. This makes the discussion of the literary material on Indonesian subjects themselves to be reduced compared with the literary material in the Indonesian language subjects of the previous curriculum. The discussion of literary texts is presented more about the content of other subjects in the text, rather than the literary aspects of literary theory. The lack of discussion of the literary aspects of Indonesian material makes the students' understanding of the literary builder's element low.

The learning time of Indonesian subjects is seven hours per week should be maximized for the development of students' literacy skills. In fact, the amount of time is allocated more for language materials. This can be seen in the number of basic competencies of language materials are more than the basic competence of literary materials. Meanwhile, literary learning has an important purpose of developing morals, writing skills, speaking, listening, and fostering a reading attitude. Through the results of the literary content analysis in the book of students as a mandatory handbook of the 4th grade of 2013 curriculum, it is necessary to develop literature materials by teachers as a supplement to increase the literary knowledge of students who have not been listed in the 2013 curriculum student books. Through the discovery of the lack of literary content in the $4^{\text {th }}$ grade in elementary schools, the teaching materials should be developed by teachers to maximize the learning of literature.

To maximize the learning of literature, the teachers should do some assignments. In the basic competence to elaborate opinions about the content of fairy tales, the material that should be developed is the discussion of the intrinsic elements of various types of old stories. The types of old stories that need to be discussed are legends, fables, fairy tales, and witty stories. The intrinsic elements that need to be introduced are the theme, character, place, and time of the story, as well as the story itself. Furthermore, it can be added to link the story with daily life so that students can practice the moral message of the story.

In the basic competence of poetry appreciation, the material that needs to be developed is to distinguish poetry with children's stories, introducing old poems and new poems, identifying intrinsic elements of poetry, writing poetry, and reading poetry. In the material types of poetry can be epitomized old poetry is pantun so that students can distinguish pantun and new poetry. In writing poetry, the students are directed in the procedure of writing poetry so that students can write poetry intact.

In the basic competence of identifying fictional characters, the material that needs to be developed is to identify fictional characters, types of fictional characters, comparisons of characters of fictional texts, and to link character characters in everyday life. Through the activities of knowing fictional characters, it is expected to develop the morale of students through exemplary characters in the story.

From the discussion, this research focuses on three points. First, the percentage of literary materials in the learning of Indonesian's 4th-grade elementary school is $30 \%$. Second, the literary material that is contained in the $4^{\text {th }}$ grade of elementary school students in Indonesia is about traditional stories, poetry, and fiction. Third, the lack of literary material contained in the student's book is limited to the ability to answer the questions written in the text so that it needs to be added to the theoretical limitations of literary concepts. In addition, the material presented is less diverse because there is a lot of repetitive material.

The difference of this research with previous research is the previous research discusses the development of learning about poetry (Aravani, 2012), the benefits of popular children's stories in learning (Wally, Lavinger, \& Grainger, 2005), and the influence of learning models on the ability to appreciate fairy tales (Nensilianti, 2012). These three kinds of research focus on the importance of literature for students as well as appropriate strategies for the success of literary learning while this research is focused on the analysis of literary learning materials used in most schools in Indonesia. In addition, there are kinds of research on the development of children's story-writing books (Neina, Mardikantoro, \& Supriyanto, 2015). The research produces an enrichment book that can be used in one of the literary learning activities, while this research produces a list of literary learning materials needed in the fourth grade of the elementary school based on student book analysis results. It is also different with research by Djuanda (2014) that is limited to the analysis of literary materials on the curriculum, while this research is the more in-depth analysis of student books.

\section{CONCLUSIONS}

Refer to the discussions, it can be concluded that theme 4 about competency to build personal statement toward literature, the learning process is only limited to reading a text to be followed by questions about that text. There is no explanation about the types of literature and its supporting elements. In the material of understanding and reading a poetry that is included in theme 6 , there is no explanation on the differences between poetries and process, characteristic of the poetry, and the technique on how to write and read poetry. Meanwhile, in theme 8 about the figures and their characteristic, the 2013 curriculum has not set the material to the understanding the figures and their characteristic, differences between fictional and nonfictional text, and the supporting elements of the literature. Therefore, there should be a development to the teaching materials for elementary students.

This research is still limited to the book for $4^{\text {th }}$-grade students in content analysis. There has been no survey of literary materials that are needed by elementary school students who are adapted to the times. It is necessary to conduct development research that produces the appropriate literary materials for the 4th-grade students of the primary school. 


\section{REFERENCES}

Aravani, E. (2012). The role of teaching poetry in developing literacy in Greek primary school: A case study. Australasian Journal of Early Childhood, 37(4), 51-58.

Djuanda, D. (2014). Pembelajaran sastra di SD dalam gamitan Kurikulum 2013. Mimbar Sekolah Dasar, 1(2), 191-200.

Irawati, R. P., \& Purwani, N. (2013). Nilai-nilai moralitas dan budaya asing dalam sastra anak terjemahan melalui pemaknaan sastra anak. Lingua, 9(1), 46-53.

Kemendikbud. (2013). Kurikulum 2013: Kompetensi dasar SD/MI. Jakarta: Kemendikbud.

Krippendorf, K. (2004). Content analysis: An introduction to its methodology. London: Sage Publications.

Neina, Q. A., Mardikantoro, H. B., \& Supriyanto, T. (2015). Pengembangan buku pengayaan menulis cerita anak bermuatan nilai karakter berdasarkan Content and Languange Integrated Learning (CLIL) untuk siswa Sekolah Dasar kelas tinggi. Seloka Jurnal Pendidikan Bahasa Dan Sastra Indonesia, 4(2), 50-57. https://doi.org/http://journal.unnes.ac.id/sju/ index.php/seloka/issue/view/885

Nensilianti, N. (2012). Model pembelajaran pemetaan cerita dalam peningkatan kemampuan mengapresiasi dongeng siswa Sekolah Dasar. Indonesian Journal of Educational Studies, 11(2).
Papalia, D. E., \& Feldman, R. D. (2014). Experience human development: Menyelami perkembangan manusia (12 ${ }^{\text {th }}$ ed.). Jakarta: Salemba Humanika.

Prastowo, A. (2012). Panduan kreatif membuat bahan ajar inovatif: Menciptakan metode pembelajaran yang menarik dan menyenangkan. Yogyakarta: DIVA Press.

Santrock, J. W. (2011). Masa perkembangan anak: Children. Jakarta: Humanika, Salemba.

Siswanto, W. (2013). Pengantar teori sastra. Malang: Aditya Media Publishing.

Suryaman, M. (2015). Analisis hasil belajar peserta didik dalam literasi membaca melalui Studi Internasional (Pirls) 2011. Litera, 14(1), 170-186. https://doi. org/10.21831/ltr.v14i1.4416

Tomlinson, B. (2011). Materials development in language teaching. Cambridge: Cambridge University Press.

Wally, L. M., Levinger, N. E., \& Grainger, D. W. (2005). Employing popular children's literature to teach elementary school chemistry: An engaging outreach program. Journal of Chemical Education, 82(10), 1489-1495. https://doi.org/10.1021/ed082p1489.

Wulan, N. S. (2014). Perkembangan mutakhir pendidikan Bahasa Indonesia: Kurikulum 2013 Sekolah Dasar. Mimbar Sekolah Dasar, 1(2), 176-184. 